\title{
A sensitive and selective fluorescent sensor for berberine chloride based on the supramolecular self-assembly of perylene diimide in aqueous solution
}

Yuwei Wu ${ }^{\ddagger}$, Qiaojuan Zhang ${ }^{\ddagger}$, Yiwen Zhao ${ }^{a}$, Kangyuan Zhuang ${ }^{a}$, Yiling Fan ${ }^{b}$, Shuo Zhang $^{a}$, Xiaohan Zhang ${ }^{a}$, Kunlun Huang ${ }^{a}$, Zhiyi Yao ${ }^{*, a}$

${ }^{\text {a }}$ College of Food Science and Nutritional Engineering, China Agricultural University and Key Laboratory of Safety Assessment of Genetically Modified Organism (Food Safety), Ministry of Agriculture, Beijing 100083, China.

b NMPA Key Laboratory for Testing Technology of Pharmaceutical Microbiology, Shanghai Institute for Food and Drug Control, Shanghai, 201203, China

*E-mail: yaozy@cau.edu.cn. Tel: +86-10-62737055; Fax: +86-10-62737055;

Number of pages: 12 (S1-S12)

Number of figures: 13 (Figure S1-Figure S13)

Number of table: 1 (Table S1) 


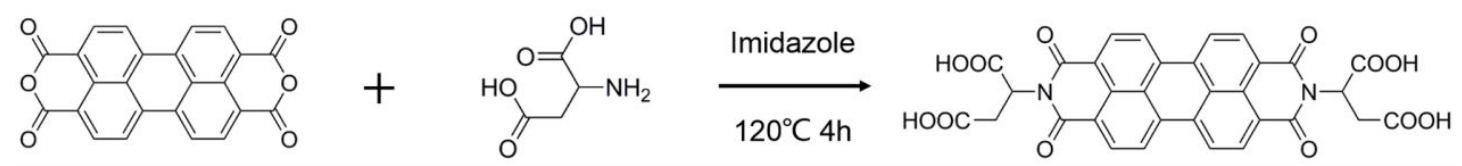

Figure S1. The scheme for the synthesis of PDI-Asp.

\section{Synthesis of probes.}

Perylene bisimide (0.196 g, $0.5 \mathrm{mmol})$, aspartic acid (Asp) (0.166 mg, $1.25 \mathrm{mmol})$ and $2.0 \mathrm{~g}$ imidazole were added in a Schlenk tube and stirred at $120^{\circ} \mathrm{C}$ for 4 hours. The resulting mixture was then cooled to room temperature and transferred into a centrifugal tube. $2.0 \mathrm{M} \mathrm{HCl}$ was added into the product to lower the $\mathrm{pH}$ and precipitate the product. After the mixture was centrifuged $(1000 \mathrm{r} / \mathrm{min}, 10 \mathrm{~min})$ and the supernatant was taken, the precipitate was washed three times with purified water, and then dried under vacuum to obtain the final product PDI-Asp (267.99mg, 86\%). ${ }^{1} \mathrm{H}-\mathrm{NMR}\left(500 \mathrm{MHz}, \mathrm{D}_{2} \mathrm{O} \mathrm{NaOD}, \mathrm{ppm}\right)$ : 8.44-7.93 (m, 8H), 6.11-5.97 (m, 2H), 3.38-3.03 (m, 4H). ${ }^{13} \mathrm{C}-\mathrm{NMR}\left(125 \mathrm{MHz}, \mathrm{DMSO}-d_{6}, \mathrm{ppm}\right): 172.34,170.77,162.36$, $134.03,131.26,128.35,125.23,123.86,122.17,50.13,34.62$. Exact mass calcd for $\mathrm{C}_{32} \mathrm{H}_{18} \mathrm{~N}_{2} \mathrm{O}_{12}: 622.09$. Found: 621.08 . [M-H] $]^{-}$. Solubility in basic water: $11.5 \mathrm{mg} / \mathrm{mL}$. The synthesis of the other three probes was similar to the above procedures.

PDI-Glu (80\%): ${ }^{1} \mathrm{H}-\mathrm{NMR}\left(300 \mathrm{MHz}, \mathrm{D}_{2} \mathrm{O} \mathrm{NaOD}\right.$, ppm): 8.25-7.68 (m, 8H), 5.45-5.42 (m, 2H), 2.60-2.04 (m, 8H). PDI-CysA (80\%): ${ }^{1} \mathrm{H}-\mathrm{NMR}\left(300 \mathrm{MHz}, \mathrm{D}_{2} \mathrm{O} \mathrm{NaOD}\right.$, ppm): 8.12-7.63 (m, 8H), 6.03-5.93 (m, 2H), 3.95-3.71 (d, 4H). PDI-Ala (85\%): ${ }^{1} \mathrm{H}-\mathrm{NMR} \quad\left(300 \mathrm{MHz}\right.$, DMSO- $\left.d_{6}, \mathrm{ppm}\right): 8.45-8.23(\mathrm{~m}, 8 \mathrm{H}), 5.65-5.57 \quad(\mathrm{~m}, 2 \mathrm{H})$, $1.71-1.65(\mathrm{~d}, 6 \mathrm{H})$. 

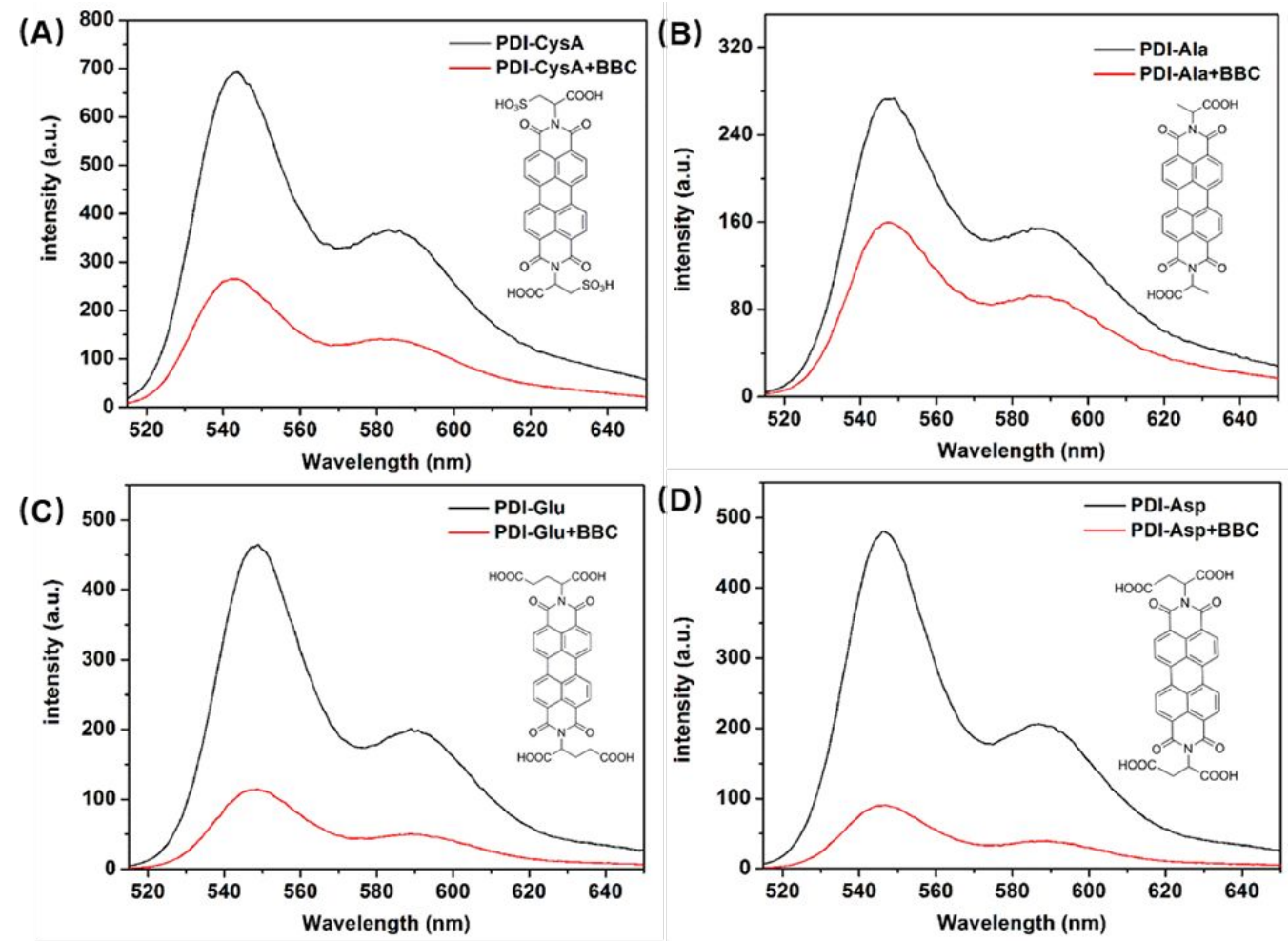

Figure S2. Emission spectra of different probes in the absence and presence of BBC in Tris-HCl buffer $(1 \mathrm{mM}, \mathrm{pH}=8.0)$. [PDI-Asp] $=2.5 \mu \mathrm{M},[\mathrm{BBC}]=25.0 \mu \mathrm{M} . \lambda_{\mathrm{ex}}=$ $495 \mathrm{~nm}$.

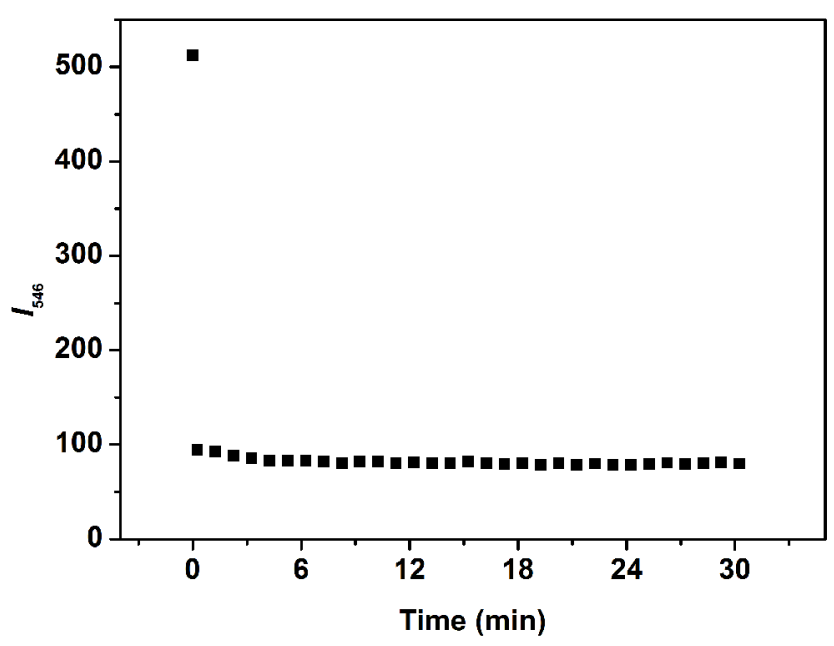

Figure S3. Time-dependent fluorescent intensity at $546 \mathrm{~nm}$ of PDI-Asp in the absence and presence of BBC in Tris-HCl buffer $(1 \mathrm{mM}, \mathrm{pH}=8.0)$. [PDI-Asp] $=2.0$ $\mu \mathrm{M},[\mathrm{BBC}]=25.0 \mu \mathrm{M} . \lambda_{\mathrm{ex}}=495 \mathrm{~nm}$. 

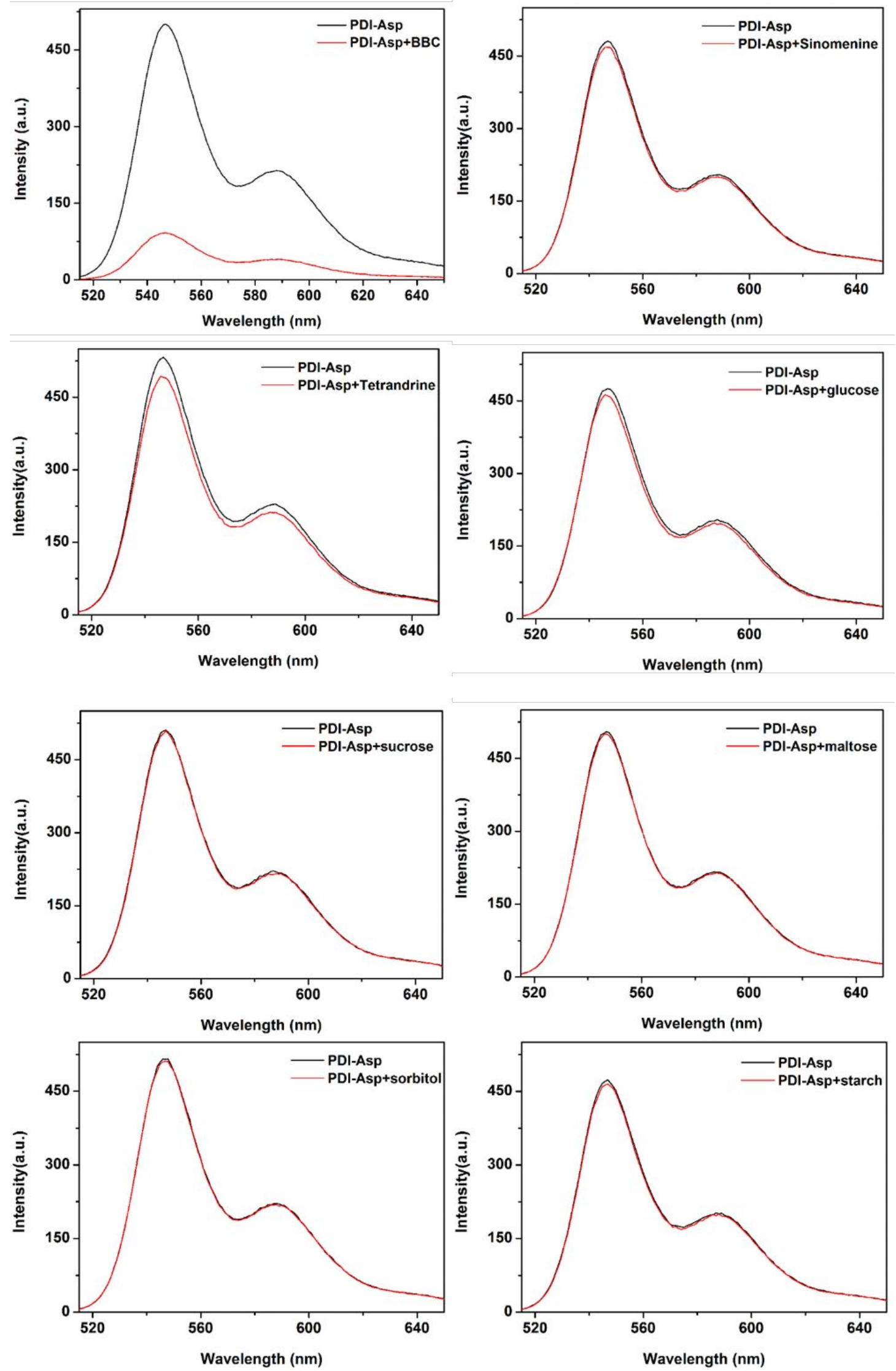

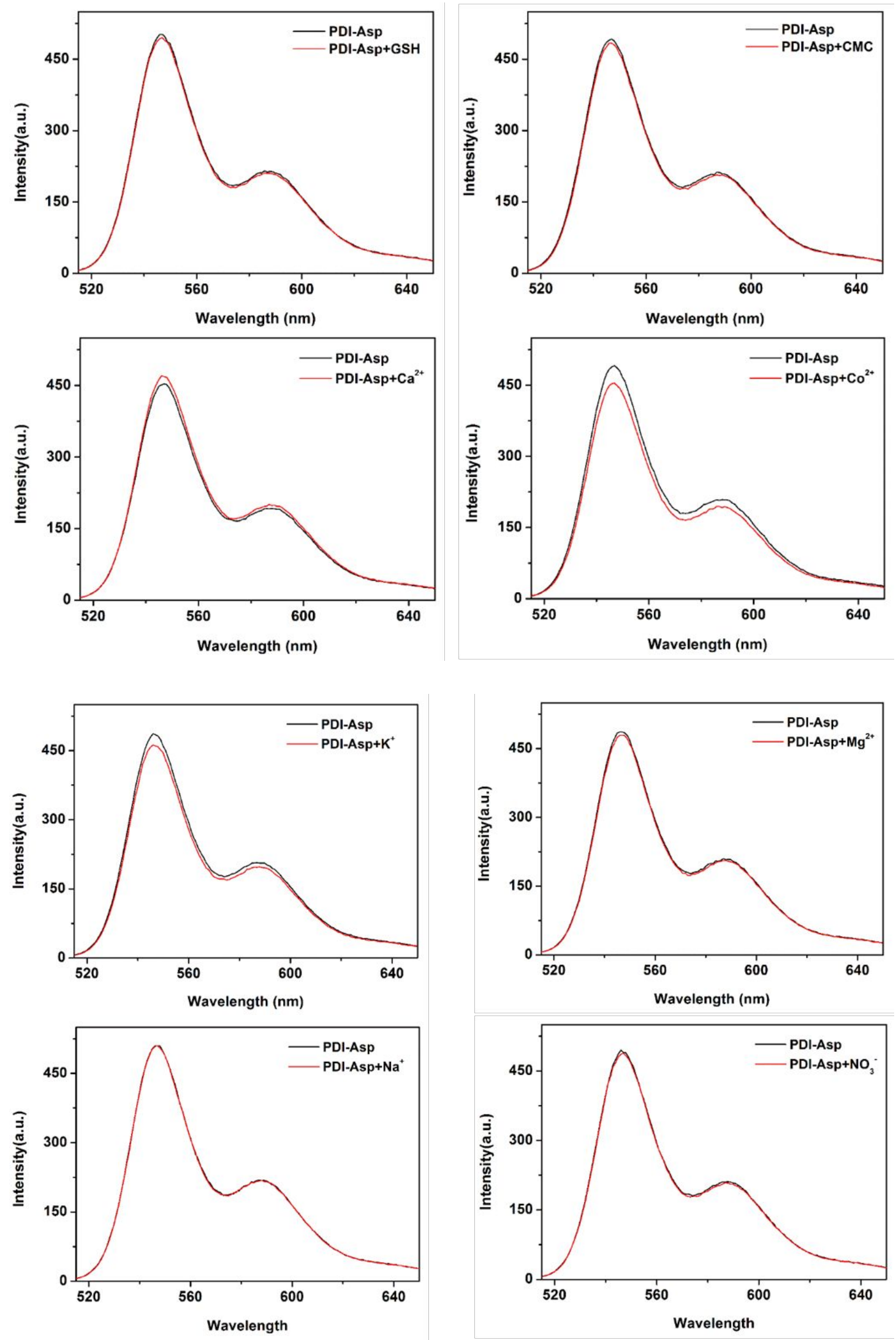

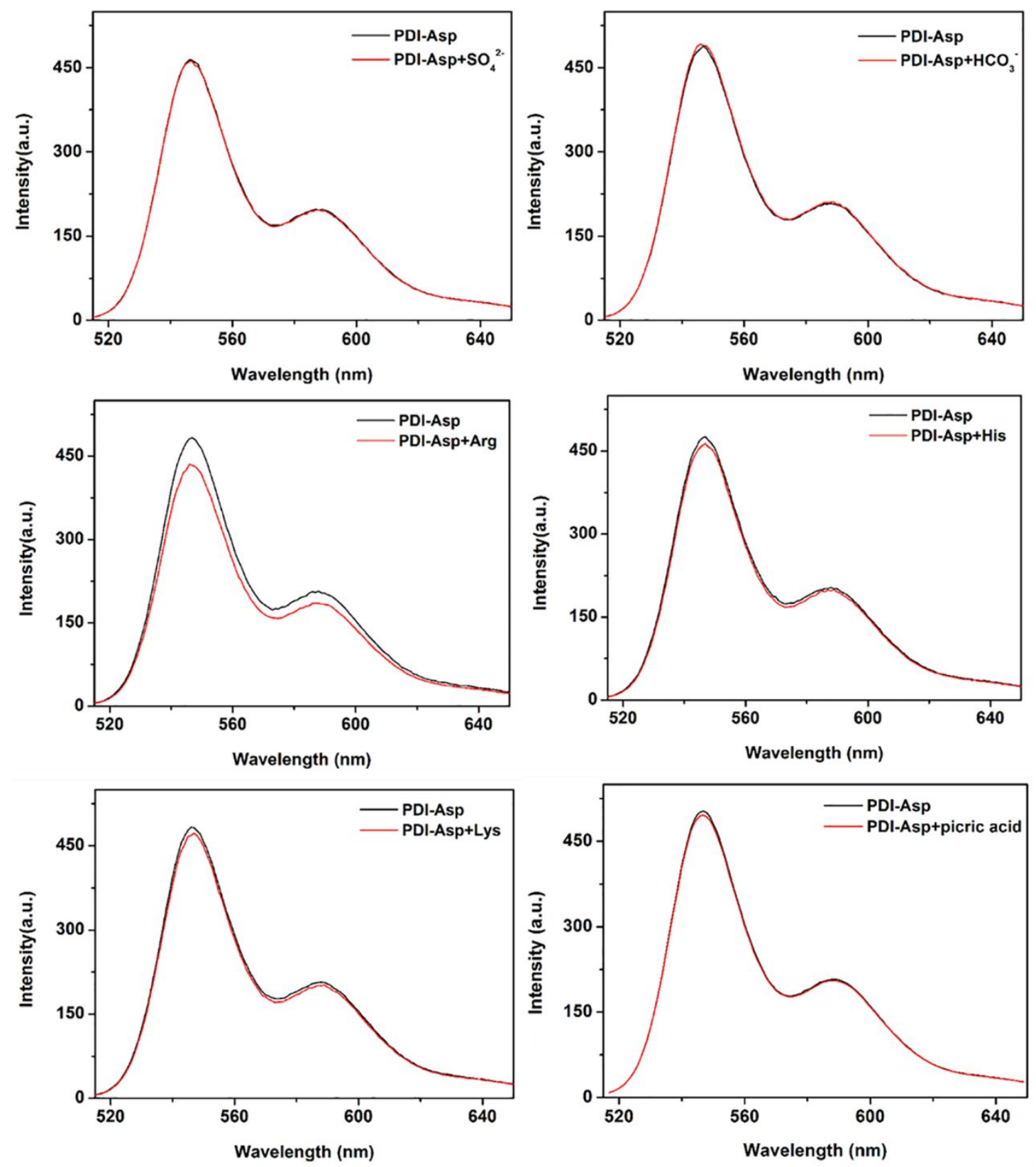

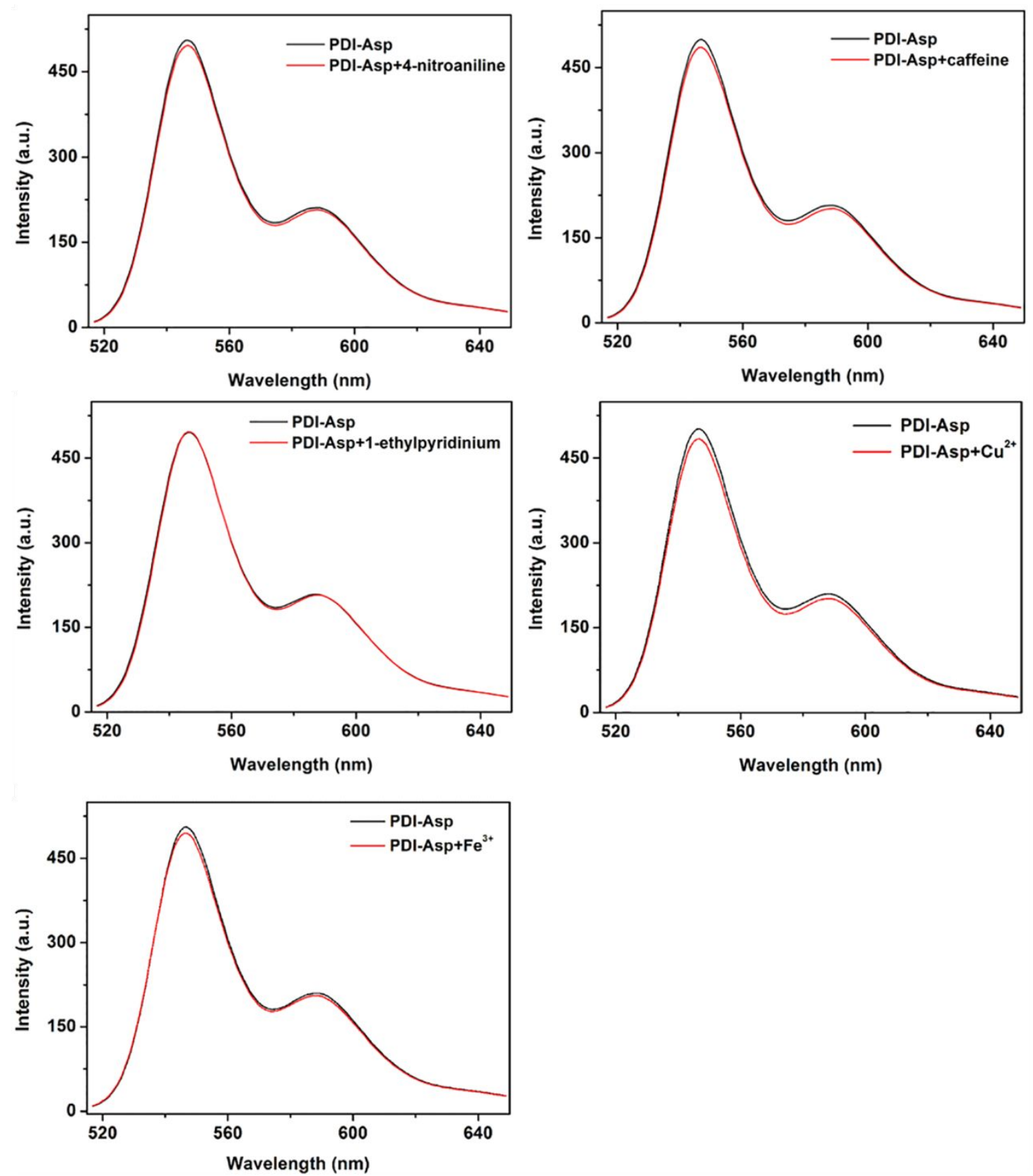

Figure S4. Emission spectra of PDI-Asp in the absence and presence of various analytes in Tris-HCl buffer $(1 \mathrm{mM}, \mathrm{pH}=8.0)$. [PDI-Asp] $=2.0 \mu \mathrm{M}$, [analytes] $=25.0$ $\mu \mathrm{M} . \lambda_{\mathrm{ex}}=495 \mathrm{~nm}$. 


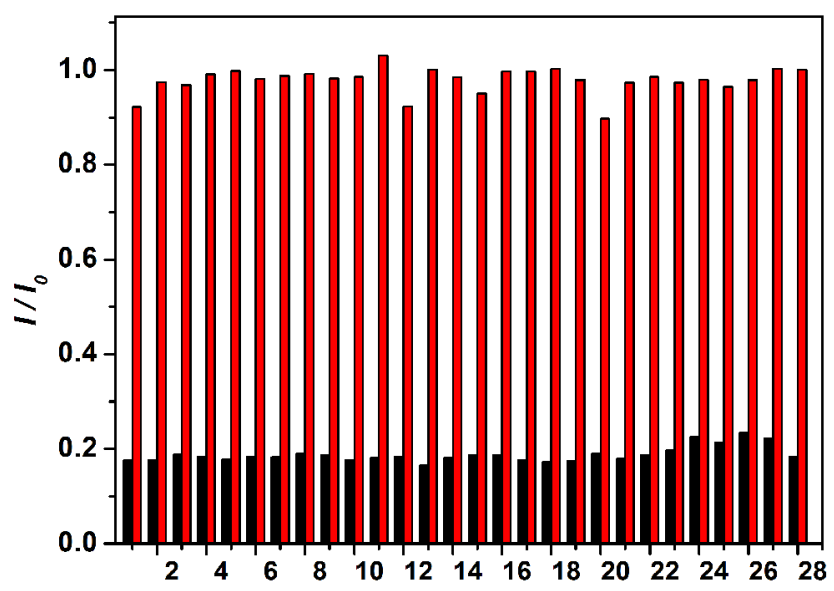

Figure S5. The relative intensity $\left(I / I_{0}\right)$ of PDI-Asp at $546 \mathrm{~nm}$ in the absence (red column) and in the presence (black column) of $\mathrm{BBC}$ with other different interfering substances in Tris-HCl buffer $(1 \mathrm{mM}, \mathrm{pH}=8.0) . \lambda_{\mathrm{ex}}=495 \mathrm{~nm} .1$ tetrandrine; 2 sinomenine; 3 glucose; 4 maltose; 5 sucrose; 6 starch; 7 mannitol; 8 sorbitol; 9 CMC; $10 \mathrm{GSH} ; 11 \mathrm{Ca}^{2+} ; 12 \mathrm{Co}^{2+} ; 13 \mathrm{Na}^{+} ; 14 \mathrm{Mg}^{2+} ; 15 \mathrm{~K}^{+} ; 16 \mathrm{NO}_{3}^{-} ; 17 \mathrm{SO}_{4}{ }^{2-} ; 18 \mathrm{HCO}_{3}{ }^{-} ; 19$ Lys; 20 Arg; 21 His; 22 picric acid; 23 caffeine; 24 4-nitroaniline; $25 \mathrm{Cu}^{2+}$; $26 \mathrm{Fe}^{3+}$; 27 1-ethylpyridinium; 28 blank. [PDI-Asp] $=2.0 \mu \mathrm{M}$, [analytes $]=25.0 \mu \mathrm{M}$.

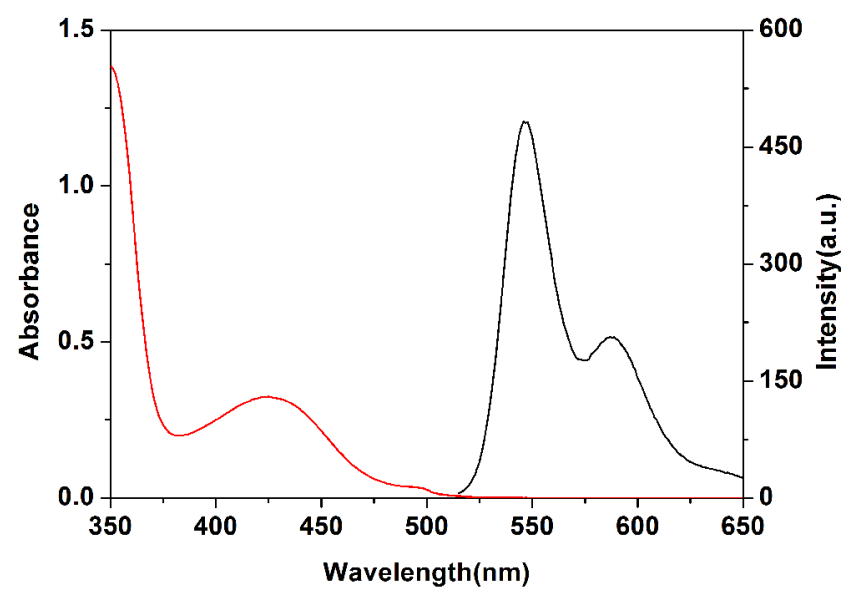

Figure S6. Absorption spectra of BBC (left axis, red line) and emission spectra of PDI-Asp (right axis, black line) in Tris- $\mathrm{HCl}$ buffer $(1 \mathrm{mM}, \mathrm{pH}=8.0)$. [PDI-Asp] $=$ $2.0 \mu \mathrm{M},[\mathrm{BBC}]=50.0 \mu \mathrm{M} . \lambda_{\mathrm{ex}}=495 \mathrm{~nm}$. 


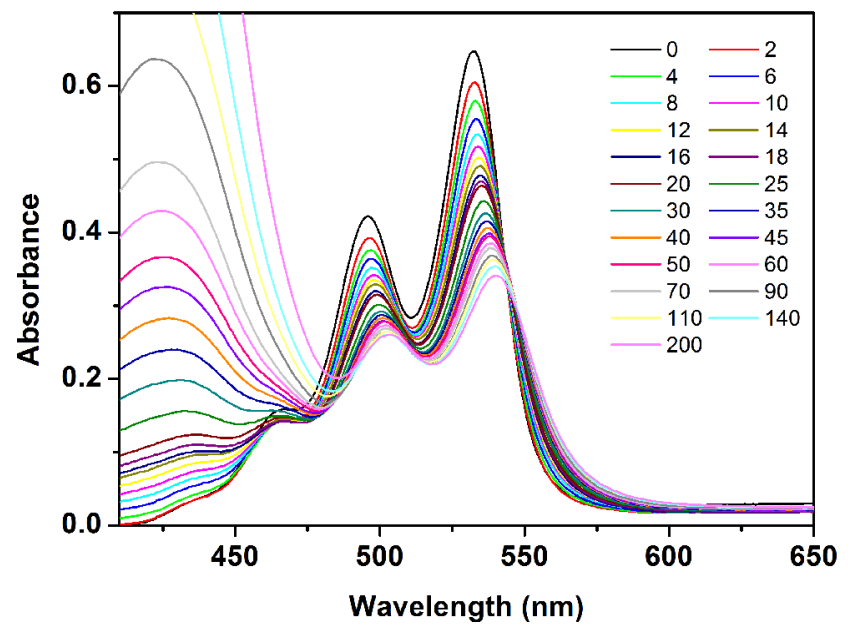

Figure S7. Absorption spectra of PDI-Asp in the absence and the presence of increasing concentrations of $\mathrm{BBC}$ as indicated in Tris- $\mathrm{HCl}$ buffer $(1 \mathrm{mM}, \mathrm{pH}=8.0)$. $[\mathrm{PDI}-\mathrm{Asp}]=10.0 \mu \mathrm{M}$.

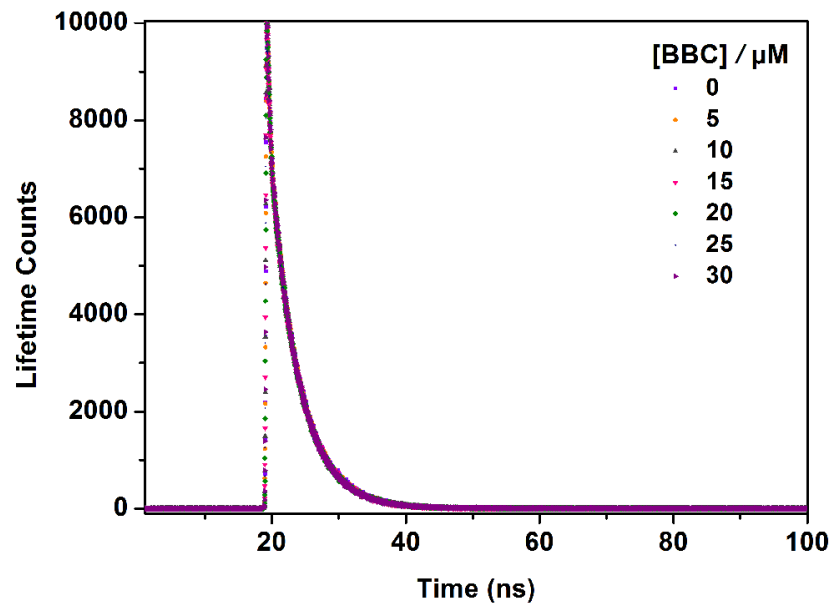

Figure S8. Time-resolved decay of PDI-Asp with different concentrations of BBC as indicated in Tris- $\mathrm{HCl}$ buffer $(1 \mathrm{mM}, \mathrm{pH}=8.0)$. [PDI-Asp] $=2.0 \mu \mathrm{M}$. 


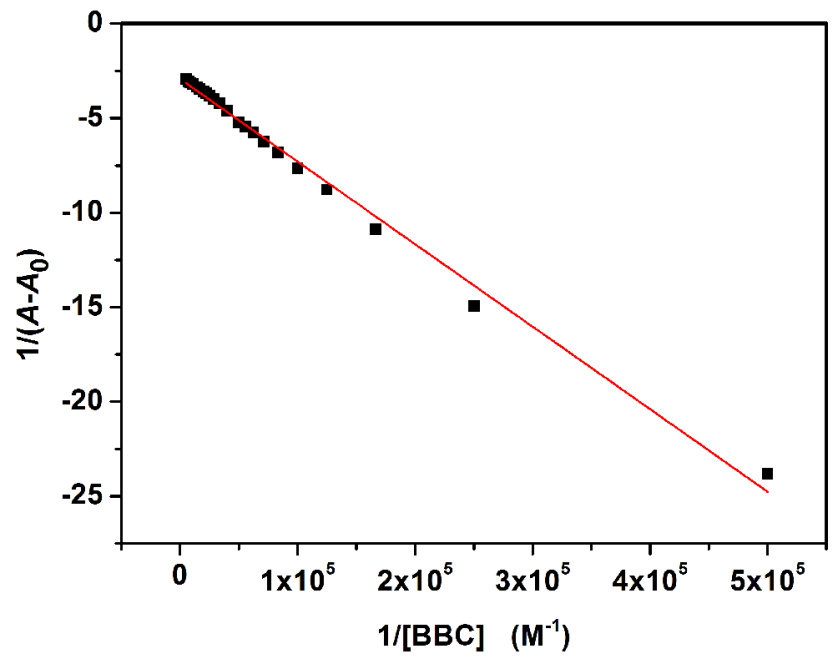

Figure S9. Benesi-Hildebrand plot of PDI-Asp with BBC. [PDI-Asp] $=10.0 \mu \mathrm{M}$.

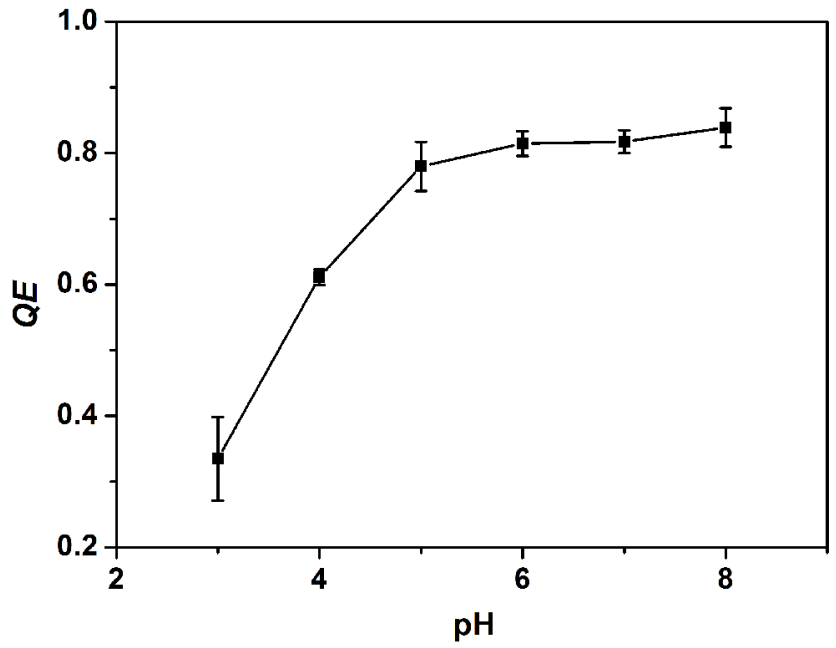

Figure S10. Effects of different $\mathrm{pH}$ on the relative fluorescence intensity of $Q E$ (1- $I$ / $I_{0}$ ), Where $I_{0}$ and $I$ represent the fluorescence intensity of PDI-Asp at $546 \mathrm{~nm}$ in the absence and presence of BBC in Tris- $\mathrm{HCl}$ buffer $(1 \mathrm{mM})$, respectively. $\lambda_{\mathrm{ex}}=495 \mathrm{~nm}$. 


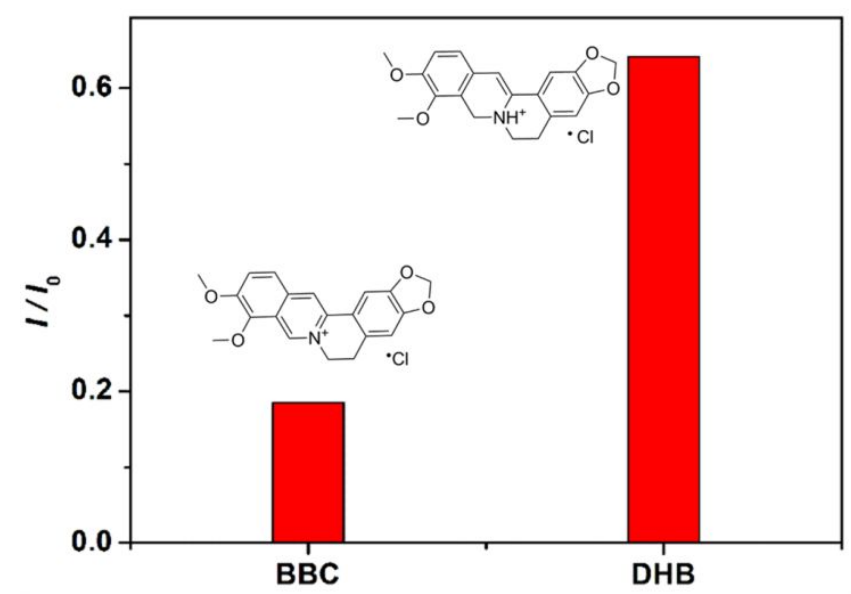

Figure S11. The relative intensity $\left(I / I_{0}\right)$ of PDI-Asp, where $I_{0}$ and $I$ represent the fluorescence intensity of PDI-Asp at 546nm in the absence and presence of BBC or DHB, respectively. Tris-HCl buffer $(1 \mathrm{mM}, \mathrm{pH}=8.0)$. [PDI-Asp $]=2.0 \mu \mathrm{M},[\mathrm{DHB}]=$ $[\mathrm{BBC}]=25.0 \mu \mathrm{M} . \lambda_{\mathrm{ex}}=495 \mathrm{~nm}$.

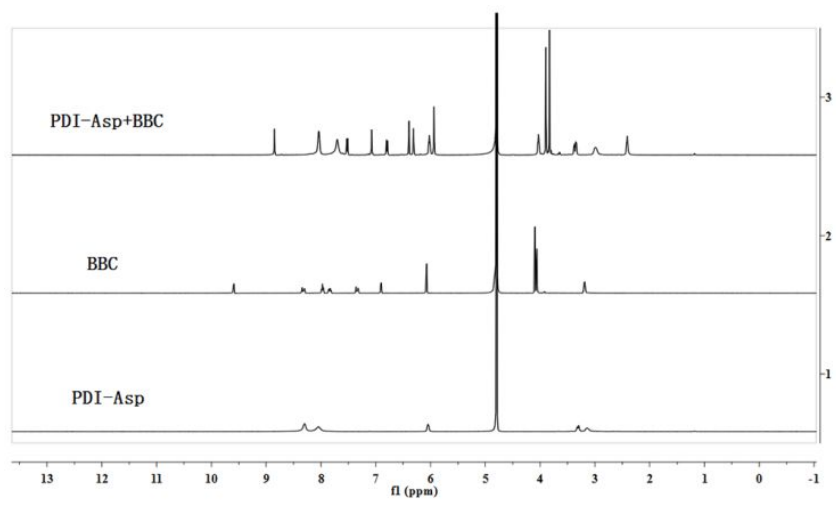

Figure S12. ${ }^{1} \mathrm{H}-\mathrm{NMR}$ spectra of PDI-Asp, BBC and a mixture of them in $\mathrm{D}_{2} \mathrm{O}$. $[\mathrm{PDI}-\mathrm{Asp}]=[\mathrm{BBC}]=5.0 \mathrm{mM}$. 


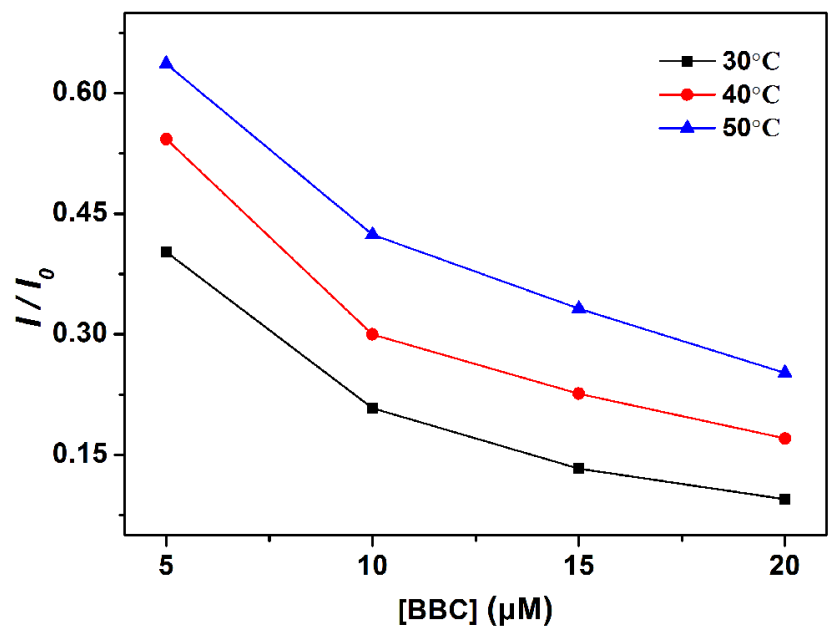

Figure S13. The relative intensity $\left(I / I_{0}\right)$ of PDI-Asp with concentration of BBC (5.0 $\mu \mathrm{M}-25.0 \mu \mathrm{M})$ at different temperatures $\left(30^{\circ} \mathrm{C} 、 40^{\circ} \mathrm{C} 、 50^{\circ} \mathrm{C}\right) .[$ PDI-Asp] $=2.0 \mu \mathrm{M}$, Tris-HCl buffer ( $1 \mathrm{mM}, \mathrm{pH}=8.0)$. $\lambda_{\mathrm{ex}}=495 \mathrm{~nm}$. 
Table S1 Real samples detection of BBC.

\begin{tabular}{cccc}
\hline \multirow{2}{*}{ Samples } & \multicolumn{3}{c}{ The proposed method } \\
\cline { 2 - 4 } & $\begin{array}{c}\text { Label claim } \\
\left(\mathrm{mg} \mathrm{tablet}^{-1}\right)\end{array}$ & $\begin{array}{c}\text { The proposed method } \\
\left(\mathrm{mg} \mathrm{tablet}^{-1}\right)\end{array}$ & RSD (\%) \\
\hline $\begin{array}{c}\text { Compound } \\
\text { Aucklandia and } \\
\text { Berberine Tablets }\end{array}$ & 50 & $\mathbf{4 8 . 6 3 \pm 1 . 2 0}$ & 2.41 \\
\hline $\begin{array}{c}\text { Berberine } \\
\text { Hydrochloride Tablets }\end{array}$ & 100 & $100.69 \pm 3.70$ & 3.70 \\
\hline
\end{tabular}

